Research Article

\title{
The Association between Periodontal Disease on Pregnancy and the Incidence of Preterm Labor
}

\author{
Hubungan antara Penyakit Periodontal dengan Angka Kejadian Persalinan Preterm
}

\author{
Andoharman Damanik, Tjokorda GA Suwardewa \\ Department of Obstetrics and Gynecology \\ Faculty of Medicine University of Udayana/ \\ Sanglah Hospital \\ Denpasar
}

\begin{abstract}
Objective: To determine the association between periodontal disease on pregnancy and the incidence of preterm labor.

Method: This was a cross sectional study. We enrolled sixty subjects, which then divided into two groups. One group comparised of thirty pregnant women preterm delivery and thirty women with preterm pregnancy. Subjects were chosen by consecutive sampling method. The subject's teeth except Molar III were evaluated for probing depth, bleeding on probing, calculus, and the results were interpreted according to CPITN (WHO,1997). Evaluation were conducted at Dental and Oral Health Clinic at Sanglah Hospital and Gianyar Hospital.

Results: The subjects characteristic was not different between the two groups, hence its influence could be avoided. Using Chi-Square test, we found that periodontal disease on pregnant women was associated with preterm birth, with prevalence ratio of 2.30 (CI 95\% 1.69-3.13, $\mathrm{p}=0.011$ ).
\end{abstract}

Conclusion: Diseases on pregnant mother is associated with the incidence of preterm labor. Periodontal diseases is found twice as many in women with preterm labor compared to pregnant woman who did not experienced any signs of preterm labor.

[Indones J Obstet Gynecol 2012; 36-2: 85-9]

Keywords: periodontal disease, preterm birth

\begin{abstract}
Abstrak
Tujuan: Untuk mengetahui hubungan antara penyakit periodontal pada perempuan hamil dengan angka kejadian persalinan preterm.

Metode: Penelitian ini merupakan penelitian cross-sectional analitik. Subjek penelitian sebesar 60 ibu hamil yang dibagi menjadi dua kelompok, 30 ibu hamil preterm inpartu dan 30 ibu hamil preterm tidak inpartu. Subjek dipilih secara consecutive sampling. Pada subjek penelitian dilakukan evaluasi semua gigi kecuali molar III menggunakan pemeriksaan Probing Depth dan Bleeding On Probing, pencatatan adanya kalkulus, dan selanjutnya hasil diinterpretasikan menurut CPITN, 1997 (WHO). Evaluasi dilakukan di Poli Gigi dan Mulut RSUP Sanglah dan RSUD Gianyar.

Hasil: Karakteristik subjek penelitian tidak berbeda bermakna antara kedua kelompok sehingga pengaruhnya dapat diabaikan. Penyakit periodontal pada ibu hamil ditemukan memiliki hubungan dengan persalinan preterm melalui uji Chi-square dengan nilai rasio prevalen 2,30 (IK 95\% 1,69-3,13; $p=0,011$ ).

Kesimpulan: Pada penelitian ini disimpulkan penyakit periodontal pada ibu hamil berhubungan dengan angka kejadian persalinan preterm yaitu pada ibu hamil dengan penyakit periodontal maka kejadian persalinan preterm adalah 2 kali lebih tinggi dibandingkan ibu hamil yang tidak menderita penyakit periodontal sebelum dan selama hamil.

[Maj Obstet Ginekol Indones 2012; 36-2: 85-9]

Kata kunci: penyakit periodontal, persalinan preterm
\end{abstract}

Correspondence: Andoharman Damanik, Department of Obstetrics and Gynecology, Faculty of Medicine University of Udayana, Denpasar, Phone: 085238586831, Email: andodamanik@yahoo.co.id

\section{INTRODUCTION}

Recently, the rate of neonatal mortality and morbidity on preterm baby is still very high. Compared to full term neonates, preterm babies, especially those who were born on $<32^{\text {nd }}$ week of gestational age, have mortality risk 70 times higher than full term babies, because they have difficulties to adapt with the environment outside of the uterus, which is related to the maturity of the organs of newborn baby such as lungs, heart, liver, brain, and gastrointestinal. About one fifth of the babies born on $<32^{\text {nd }}$ week of gestational age cannot survive within their first year, while only $1 \%$ of neonatal death occurs in babies born on the $35^{\text {th }}-36^{\text {th }}$ week of gestational age, and $0.3 \%$ of a full termneonates. As we know, the problems that often tag along with preterm baby includes neonatal systemic inflammatory response syndrome (SIRS), periventricular leucomacia (PVL), intraventricular hemorrhage (IVH), necrotizing enterocolitis (NEC), respiratory distress syndrome (RDS), cerebral palsy, deafness and blindness. ${ }^{1-2}$

Worldwide, it is found that about $70 \%$ of perinatal death caused by preterm labor and almost all of the cases will develop long term neurological ab- 
normality. ${ }^{3}$ In the western countries, up to $80 \%$ of neonatal death caused by prematurity, and $10 \%$ of the survivors will develop long term problems. In the US during 2001, 28.000 neonates died within their first years of life, $51 \%$ of them are neonates born on $<32^{\text {nd }}$ week of gestational age. Thirteen percent of them are born on $32^{\text {nd }}-36^{\text {th }}$ week of gestational age. ${ }^{4}$

In most cases, the major cause of preterm labor is unknown, despite all the researches being conducted for the last three decades. But many risk factors are thought to have a role in the occurrence of preterm labor, such as overdistention, uterine abnormality, anomaly of the conception result, infection, another medical abnormality of the mother, including demographic and socio-economical factor. ${ }^{5}$

One of the etiologic factor which is potential to be treated and has been gaining much attention is maternal infection. At 2006, Ritson has successfully documented that infection and inflammation of upper and lower genital tract in pregnant mother, as well as places far from pelvis, may play an ultimate role as the etiology of preterm labor. ${ }^{6}$

Nowadays, there are many evidences showed that one third of spontaneous preterm labor correlates with the presence of intrauterine infection through its products, such as bacterial toxin, bacterial phospholipase and cytokine. ${ }^{7}$

Recently, infections of the oral cavity are recognized to have contribute to preterm labor, premature rupture of the membrane or chorioamnionitis. Offen Bacher et al is the first one who report that periodontal disease as a statistically significant risk factor influencing preterm labor. ${ }^{8}$

Periodontal disease is a series of infections that cause inflammation at gingiva and periodontal tissue, and progressive alveolar's bone deficit. ${ }^{9-10} \mathrm{Pe}-$ riodontal is a tissue that surrounding all over and supporting teeth, and consists of gingiva, periodontal ligament, cementum, and alveolar bone. ${ }^{11-12}$

Physiological changes that happened inside oral cavity could be documented nowadays. There is estrogen and progesterone receptor inside gingiva's cells. Among the pregnancy, these hormon's production are increased, therefore brings few changes involving increasing of vascularization, liquid permeability, and gingival sensitivity. ${ }^{6}$ These gingival transformations are responsible to increase gingivitis in pregnancies, commonly starts at the second or third month of pregnancy. ${ }^{13}$
The experts in periodontal, gynecologists, and epidemiologists found that $18 \%$ of preterm labor on had periodontal disease, ${ }^{14}$ more frequent than with maternal age, race, parity of more than 5 and smoker or alcohol consumer. The most common form of periodontal infection are gingivitis and periodontitis. The two forms of infection are frequently found on pregnant mother, i.e. about 30\% for gingivitis and $5-20 \%$ for periodontitis. ${ }^{1}$

Some criteria are used to diagnose the periodontal disease, one of them using the criteria of The Community Periodontal Index of Treatment Needs (CPITN) which released by World Health Organization. $^{12}$

\section{METHOD}

This was a cross-sectional study with consecutive sampling method. Samples were divided into 2 groups, which is preterm birth group and preterm pregnancy group. Then, each sample was evaluated to find whether the subject has got a periodontal disease.

This study was conducted in Delivery Room, Obstetrics and Gynecology Polyclinic, and Oral and Dental Health Polyclinic of Sanglah General Hospital Denpasar and Gianyar Hospital. The population of this study was every pregnant woman that came to either the delivery room or to Obstetrics and Gynecology Polyclinic to do antenatal checkup, at Sanglah General Hospital Denpasar and Gianyar Hospital. They had to fulfill the inclusion criteria, which was woman in gestational age of 28 to 37 weeks, single and live fetus, and willing to been rolled in the study. The exclusion criteria was pregnant woman with systemic disease (cardiac abnormality, diabetes mellitus, chronic lung disease, chronic hypertension, preeclampsia/eclampsia, anemia, and urinary tract infection), history of previous preterm labor, fatal congenital abnormality, placenta previa/solutio placenta. All of the study subjects would be examined by the dentist from the Oral and Dental Polyclinic of Sanglah General Hospital and Gianyar Hospital. All teeth would be evaluated, except molar III. Probing Depth (PB) in millimeter was done on mesiobuccal position, buccal, distobuccal, distolingual, lingual, and mesiolingual for every teeth except molar III. Bleeding on Probing (POB) on six sides were recorded, and was stated to be positive if the bleeding happened within 15 seconds after probing. The presence of 
calculus were recorded. The interpretation of the result was according to CPITN (WHO, 1997): $0=$ Healthy, 1 = Bleeding on probing (BOP), 2 = Calculus supra dan sub-gingival, $3=$ Shallow pockets (3.5-5.5 mm), $4=$ Deep pockets $(>6 \mathrm{~mm})$. Periodontal disease positif if find 3 or 4 at CIPTN index. The data were analyzed using the aid of SPSS 16 version for windows. Data normality using Shapiro-Wilks test and data homogeneity using Levene's T test. The association between periodontal disease on pregnant mother and the incidence of preterm labor was tested using Chi-square test. Analysis results were presented on a table and narration.

\section{RESULT}

We examined 60 subjects comprising of 30 pregnant mothers with preterm delivery and 30 pregnant mothers with preterm pregnancy during the period of April 2010 to December 2011 with crosssectional study design in The Department of Obstetrics and Gynecology Faculty of Medicine University of Udayana Sanglah General Hospital Denpasar and Gianyar Hospital. The data are presented in a table or narration.

The data of subject characteristic from both groups are presented in Table 1.

Table1. Age Average, Gestational Age, Parity, and Length of Educationon The Group of Preterm Birth and Preterm Pregnancy

\begin{tabular}{lccc}
\hline \hline \multirow{1}{*}{ Variable } & \multicolumn{2}{c}{ Preterm pregnancy } & \\
\cline { 2 - 3 } & $\begin{array}{c}\text { Labor } \\
(\mathbf{n = 3 0 )}\end{array}$ & $\begin{array}{c}\text { NonLabor } \\
\mathbf{( n = 3 0 )}\end{array}$ & $\mathbf{p}$ \\
\hline Age (years) & $26.33 \pm 5.467$ & $28.58 \pm 6.699$ & 0.162 \\
$\begin{array}{l}\text { Length of Educa- } \\
\text { tion (years) }\end{array}$ & $11.2 \pm 1.562$ & $11.8 \pm 1.562$ & 0.142 \\
$\begin{array}{l}\text { Gestational age } \\
\text { (weeks) }\end{array}$ & $33.67 \pm 2.023$ & $33.63 \pm 2.385$ & 0.954 \\
Parity & $0.57 \pm 0.858$ & $0.63 \pm 0.809$ & 0.758 \\
\hline
\end{tabular}

Based on analysis result, the characteristic of the subject between the group of preterm birth and preterm pregnancy did not have any significant difference.

In order to determine the association between periodontal disease and the incidence of preterm labor, we performed Chi-Square test. The results are presented in Table 2 .
Table 2. The Association between Periodontal Disease on Pregnant Mother and the Incidence of Preterm Labor

\begin{tabular}{|c|c|c|c|c|c|c|}
\hline & \multicolumn{2}{|c|}{ Preterm Pregnancy } & \multirow{2}{*}{$\mathbf{R P}$} & \multirow{2}{*}{ CI 95\% } & \multirow{2}{*}{$\mathbf{p}$} \\
\hline & & Labor & Non Labor & & & \\
\hline \multirow{3}{*}{ CIPTN } & Positive & 7 & 0 & & & \\
\hline & & & & 2.30 & $1.69-3.13$ & 0.011 \\
\hline & Negative & 23 & 30 & & & \\
\hline
\end{tabular}

Table 2 showed that on pregnant women with periodontal disease, the incidence of preterm labor is twice as many compared to the group without periodontal disease.

\section{DISCUSSION}

During this study, 60 people were enrolled as sample after fulfilling the inclusion and exclusion criteria, comprising of 30 people in the group of preterm birth and another 30 people in the group of preterm pregnancy. Based on analytical result, the characteristic of subjects between preterm birth group and preterm pregnancy group were found to have no difference, hence its influence could be ignored.

From this study, 7 samples were found to have periodontal disease, all from the group of preterm birth and none from preterm pregnancy group. We also found that as many as 53 samples were devoid of periodontal disease, of which 23 samples were from the group of preterm birth and 30 samples were from preterm pregnancy group in detail. This number showed that periodontal infection on pregnant mother had a correlation with the incidence of preterm labor. This fact was encouraged by Chi-Square test which was done to determine the association between periodontal disease on pregnant women and the incidence of preterm labor, where pregnant women with periodontal disease were found, thus the incidence of preterm labor was twice compared to those without periodontal disease (prevalence ratio 2.30, CI 95\% 1.69-3.13, p 0.011).

This result is supported by a theory that oral cavity infections also contribute to the incidence of preterm labor. Offen Bacher et al were the first to report about periodontal disease as statistically significant risk factor that influenced preterm labor. ${ }^{8}$ Periodontal infection is seven times more frequently associated with preterm labor. ${ }^{14}$ This disease is a bacterial infection, which possesses the 
ability to induce immune and inflammatory response. The most common forms of periodontal diseases are gingivitis and periodontitis. Those two forms of infections are frequently seen on pregnant mother, i.e. about $30 \%$ for gingivitis and $5-20 \%$ for periodontitis. ${ }^{1}$ The study of Oral Condition and Pregnancy found that periodontal tissue infection can increase the relative risk of spontaneous preterm labor (RR 1.6, CI 95\% 1.1-2.3). ${ }^{1}$

Periodontal disease will influence the pregnancy through following mechanisms: hematogenous spread of living bacteria in periodontal to the fetoplacental unit and the translocation of bacterial products indirectly (such as: endotoxin, specific lipopolysaccharide/LPS). Pro-inflammatory mediator like PG-E $E_{2}$ and interleukin 1- $\beta$ (IL-1 $\beta$ ) on the women with preterm labor, the level are found to be higher in gingival crevicular fluid (GCF) and blood serum. ${ }^{8}$ This happens after the stimulation of bacterial lipopolysaccharide (LPS) as well as the response in localizing the non-disseminating Porphyromonas gingivalis infection (the most common periodontal infection). This including the presence of bacterial products translocation, some of them are LPS and some inflammatory mediator (especially IL-1, IL-6, TNF- $\alpha$, PG0E $_{2}$ ). These inflammatory mediators (PG-E 2 and TNF- $\alpha$ ) are produced locally in the periodontium, with the influence from LPS, and due to high vascularity of this organ, they will spread to systemic flow during the process of inflammation. ${ }^{14-15}$

The incidence of spontaneous preterm labor associated with infection has not been satisfactorily explained. Other microorganisms have been studied as the cause of infection which associated with preterm labor, other than maternal periodontitis, such as: intra uterine infection, lower genital tractinfection (Bacterial vaginosis, Trichomoniasis, chlamydia infection), systemic infection, subclinical bacteriuria, etc. ${ }^{1}$ The exact time of infection/inflammatory process or how long latent period is before the symptoms persistis needed to be known. It is assumed that infection may happen earlier in the pregnancy and remain undetected for months. From some studies, it is consistently described that bacterial infection cause spontaneous preterm labor. It is thought that if the organisms have been persisted for 4 to 8 weeks during middle gestational age, the infection will be symptomatic and causing spontaneous preterm labor. ${ }^{16}$

\section{CONCLUSION}

Periodontal disease on pregnant mother is associated with the incidence of preterm delivery. Periodontal diseases is found twice as many in women with preterm labor compared to pregnant woman who did not experienced preterm labor signs. Based on this result, when doing routine antenatal checkup for the health of mother and fetus, it is suggested that routine oral and dental checkup especially periodontal disease is performed on pregnant mother before and during pregnancy regularly, because periodontal disease can increase the incidence of preterm labor. The hygiene of oral and dental shoud be kept during pregnancy.

\section{REFERENCES}

1. Krisnadi SR, Effendi JS, Pribadi A. Ed. Prematuritas. 2009 Bandung: Refika Aditama

2. Geophert AR, Andrews WW, Carlo W, Ramsey PS, Cliver SP, Goldenberg RL. Umbilical cord plasma interleukin-6 concentrations in preterm infant and risk of neonatal morbidity, Am J Obstet Gynecol. 2004; 191: 1371-81

3. Suryana H, Kampono N, Hestiantoro A. 2006. Perbandingan kadar interleukin-10 serum antara wanita hamil normal dan hamil dengan ancaman persalinan preterm. Maj Obstet Ginekol Indones. 2001; 30: 120-3

4. Cunningham FG, Gant NF, Leveno KJ, Gilstrap LC, Wenstrom KD. Preterm Birth. In: Williams Obstetrics, $22^{\text {nd }}$ Edition. 2005. New York: The McGraw Hill Comp

5. Mochtar AB. Persalinan Preterm. Dalam: Ilmu Kebidanan Sarwono Prawiroharjo, edisi 4. 2008. Jakarta: Yayasan Bina Pustaka Sarwono Prawiroharjo

6. Ritson BM. Periodontal disease and Preterm Delivery: Results of a Pilot Patient Education and Intervention Feasibility Study. 2006. Unpublished manuscript.

7. Shoboksi A, Shaarawy M. Maternal serum and amniotic fluid cytokines in patiens with preterm premature rupture of membranes with and without intrauterine infection. Int J Gynecol Obstet. 2002; 79: 209-15

8. Offenbacher S, Katz V, Fertik G, Collins J, Boyd D, Maynor G. Periodontal infection as a possible risk factor for preterm low birth weight. J Periodonta. 1996; 67: 1103-13

9. Hussein A. Periodontal Affection and Pregnancy: Scope of the Problem. ASJOG. 2005; 2: 351-6

10. Mokeem SA, Molla GN, Al-Jewair TS. 2004. The prevalence and relationship between periodontal disease and preterm low birth weight infant at King Khalid University Hospital in Riyadh, Saudi Arabia. J Contemporary Dental Practice, 2004; 5(2): 1-13

11. Louro PM, Fiori HH, Steibel J, Fiori RM. 2001. Periodontal Disease in pregnancy and low birth weight. J Pediatria, 2001; 77(1): 23-8

12. Newman, Takei, Carranza. Carranza's Clinical Periodontology $9^{\text {th }}$ edition. 2002

13. Ovadia R, Zirdok R, Diaz-Romero RM. Relationship between Pregnancy and Periodontal Disease. Med Biol. 2001; 14: 104 
14. Qureshi Ambrina, Ijaz S, Syed A, Qureshi Amna, Khan AA. J Pak Med Assoc. 2005; 55(10): 448-51

15. McGaw T. Periodontal disease and preterm Delivery of Low birth weight infant. J Can Dent Assoc. 2002; 68(3): 165-9
16. Yeo BK, Lim LP, Paquette DM, William RC. Periodontal Disease. The Emergence of a Risk for Systemic Conditions: Preterm Low Birth Weight. Ann Acad Med Singapore. 2005; 34: $111-6$ 